\title{
DESKRIPSI SIFAT AGRONOMIK BERDASARKAN SELEKSI GENOTIPE TANAMAN KEDELAI DENGAN METODE MULTIVARIAT
}

\section{Discription of Agronomic and Selekction Genotipes Soybean and Multivariat Motode}

\author{
Zainol Arifin, SP.,MP *) \\ Program Studi Agroteknologi (Agroekoteknologi) Fakultas Pertanian \\ Universitas Islam Madura Pamekasan Jl. PP. Miftahul Ulum Bettet Telp/Fax.
} (0324) 321783

\begin{abstract}
ABSTRAK
Nilai korelasi antara $\mathrm{X}$ dan $\mathrm{Y}$ pada $\mathrm{X}_{5}$ adalah -0.05 , sedangkan nilai pengaruh langsungnya -0.35 . Kedua nilai ini saling berdekatan sehingga seleksi secara langsung adalah berdasarkan pada umur matang panen $\left(\mathrm{X}_{5}\right)$. Pada Tabel 6 nilai koefisien korelasi $\mathrm{X}$ dan $\mathrm{Y}$ bernilai positif , pengaruh langsung $\mathrm{X}_{2}$ dan $\mathrm{X}_{3}$ masing bernilai negatif yaitu $\mathrm{X}_{2}=-1.19$ dan $\mathrm{X}_{3}=-2.64$ maka dilakukan seleksi secara tak langsung terhadap $\mathrm{X}_{2}$ (b Berdasarkan Tabel 13 di atas, genotipe terbaik yang diseleksi secara simultan berdasarkan sifat-sifat komponen hasil yang diamati (berat biji per tanaman, berat 100 biji, jumlah biji per tanaman, jumlah polong per tanaman, umur panen, berat biji per petak) adalah genotipe 12 (Unej 2). Selanjutnya berturut-turut yang menempati peringkat kedua, ketiga dan keempat adalah genotipe Unej 1, Balitkabi 8, dan Balitkabi 10.Pada hasil analisis lintas tidak terdapat nilai koefisien korelasi $\mathrm{X}$ dan $\mathrm{Y}$ yang negatif dengan pengaruh langsung yang positif sehingga tidak dilakukan seleksi secara terbatas. Jadi seleksi langsung, seleksi tak langsung dan seleksi terbatas berdasarkan hasil analisis lintas sifat agronominya Genotipe terbaik yang diseleksi secara simultan berdasarkan sifat-sifat komponen hasil yang diamati (berat biji per tanaman, berat 100 biji, jumlah biji per tanaman, jumlah polong per tanaman, umur panen, berat biji per petak) adalah genotipe 12 (Unej 2). Selanjutnya berturut-turut yang menempati peringkat kedua, ketiga dan keempat adalah genotipe Unej 1, Balitkabi 8, dan Balitkabi 10.
\end{abstract}

Kata Kunci : Seleksi, Simultan, Sifat Komponen Hasil 


\section{PENDAHULUAN}

Kedelai adalah salah satu komoditi pangan utama setelah padi dan jagung yang merupakan sumber protein utama bagi masyarakat. Kebutuhan kedelai dari tahun ke tahun terus meningkat. Penggunaan kedelai sebagai makanan sehari-hari misalnya tempe, tahu, kecap dan susu nabati telah lama dilakukan di Indonesia, sehingga kebutuhan komoditi ini sangat tinggi. Kedelai dibutuhkan untuk memenuhi kebutuhan protein murah bagi masyarakat dalam upaya meningkatkan kualitas SDM Indonesia Sejalan dengan pertambahan jumlah penduduk maka kebutuhan kedelai semakin meningkat sehingga diperlukan program khusus peningkatan produksi kedelai dalam negeri.

Kebutuhan kedelai yang besar dan kendala-kendala produksi yang ada di Indonesia akhir-akhir ini menyebabkan sebagian besar kebutuhan kedelai di dalam negeri masih dipenuhi oleh impor yang dialokasikan untuk pemenuhan industri pengolahan kedelai. Hal ini terjadi karena produksi kedelai dalam negeri tidak mampu mengimbangi kebutuhan industri dalam negeri.

Tahun 1992 merupakan puncak produksi kedelai yakni mencapai 1,8 juta ton, sejak tahun 1993 terus menurun, hingga tahun 2003 tinggal 671.600 ton. Hal ini disebabkan gairah petani menanam kedelai turun karena dipicu masuknya kedelai impor dengan harga murah, kemudahan impor kedelai, bea masuk impor nol persen (0 \%). Tahun 2004 sampai 2006 produksi mulai meningkat namun sangat lambat yakni sebesar 723.483 ton (2004), 808.353 ton (2005) dan 746.611 ton (2006). Tahun 2007 turun kembali 20\% dari 2006 menjadi 608.000 ton. Pada tahun 2008 produksi kedelai mengalami pengingkatan sebesar $28.47 \%$ dari tahun 2007 yakni sebesar 761.21 ribu ton (Ditjen Tanaman Pangan Deptan. RI, 2008).

Potensi hasil ditingkat percobaan mencapai 2 ton atau lebih. Sementara produktivitas rata-rata kedelai nasional masih rendah. Produksi kedelai tahun 2007 mencapai 13,07 kw/ha atau 1,3 ton/ha, hal ini menunjukkan bahwa kesenjangan hasil ditingkat petani dan lembaga percobaan masih tinggi. Peluang peningkatan produktivitas kedelai dapat dicapai diantaranya dengan menggunakan varietas unggul dan bermutu yang mempunyai adaptasi luas terhadap pola tanam dan kondisi tempat penanaman serta meningkatkan populasi tanaman. Usaha untuk meningkatkan hasil persatuan luas dapat dilakukan melalui perbaikan genetik maupun faktor non genetik. Kedua faktor ini sering berinteraksi dan tercermin dalam sifat-sifat agronomi yang berperan dalam menentukan tinggi rendahnya hasil. 
Pemuliaan tanaman yang tepat merupakan salah satu cara untuk meningkatkan mutu kedelai. Pemuliaan tanaman dapat dikatakan sebagai seluruh usaha yang menuju suatu muara yaitu dihasilkannya suatu varietas atau galur baru (Hartatik, 2007). Varietas baru yang dihasilkan harus memiliki sifat yang lebih baik yang sesuai harapan sehingga dapat diterima oleh produsen serta konsumen dan dapat memberikan nilai tambah ekonomi. Hal ini dapat diusahakan dengan cara seleksi terhadap populasi tertentu dari perbendaharaan klon yang ada dan introduksi klon yang baru atau perbaikan beberapa sifat keturunan tanaman yang sudah diusahakan.

Pemuliaan kedelai ditujukan untuk mendapatkan varietas unggul yang mempunyai sifat-sifat antara lain : (a) Potensi hasil tinggi, (b) umur pendek, (c) tahan terhadap penyakit penting karat daun, bakteri busuk daun, virus dan nematoda, (d) tahan terhadap hama penting seperti lalat bibit kacang, ulat pemakan daun dan hama penghisap polong, (e) toleran terhadap tanah asam,

beradaptasi baik pada tanah tanpa pengolahan intensif, (g) toleran terhadap naungan, (h) mutu biji baik dalam hal daya simpan benih dan gizi.

Hasil merupakan sifat yang ditentukan oleh banyak komponen hasil. Komponen hasil dalam memberikan pengaruh terhadap hasil, atau satu terhadap yang lain saling bekerja sama, berinteraksi atau bahkan ada yang saling berkompetisi. Oleh karena itu untuk memilih genotipe yang berdaya hasil tinggi perlu dilakukan pengujian tentang keterkaitan antara komponen-komponen hasil dengan hasil.

Hasnam et al. (1970) menyatakan, bahwa penggunaan seleksi berdasarkan pengukuran terhadap beberapa sifat dapat efektif menambah peluang terseleksinya genotipe terpilih daripada dengan seleksi berdasarkan satu sifat. Pada tahun 1969 Pesek dan Baker membandingkan seleksi tandem dan indeks seleksi menggunakan modifikasi metode pedigree pada spesies tanaman menyerbuk sendiri. Seleksi tandem adalah seleksi berdasarkan satu sifat per siklus seleksi. Pada siklus berikutnya diseleksi sifat lain, demikian seterusnya sampai diperoleh kemajuan genetik tertentu dari sifatsifat yang dikehendaki. Hasil yang diperoleh menunjukkan bahwa indeks seleksi lebih efisien 11 sampai $471 \%$ daripada seleksi tandem. Efisiensinya meningkat dengan bertambahnya sifat yang diperhitungkan dalam indeks. Hal yang sama juga dikemukakan oleh Chatterjee dan Bahattacharyya (1986), bahwa seleksi langsung berdasarkan berat biji mungkin tidak menguntungkan. Hal ini ditunjukkan dari hasil penelitian terhadap Brassica juncea (L.) Czern \& Coss dengan menggunakan indeks seleksi 
berdasarkan beberapa sifat secara simultan. Sejumlah indeks menunjukkan efisiensi lebih tinggi dibandingkan seleksi berdasarkan berat biji saja.

\begin{tabular}{llr}
\multicolumn{2}{c}{ Percobaan yang sering } \\
dilakukan pada umumnya
\end{tabular} menggunakan peubah-peubah yang saling berkaitan. Hubungan antara peubah-peubah tersebut akan mengakibatkan tidak adanya korelasi yang bernilai nol, karena pengaruh adanya aspek yang saling berpengaruh. Analisis Multivariat (MANOVA) memberikan keuntungan, dalam kasus ini karena MANOVA mempertimbangkan variasi antar peubah, lain halnya dengan ANOVA. Hubungan antar peubah dalam ANOVA tidak diperhitungkan, sehingga hubungan antar peubah adalah nol. Walaupun pada MANOVA diperbolehkan menggunakan banyak peubah terikat, tetapi jumlah peubah tersebut tidak boleh terlalu banyak karena akan memberikan hasil yang kurang akurat (Bray dan Maxwell, 1985).

Program seleksi untuk mendapatkan tanaman yang berdaya hasil tinggi berdasarkan satu sifat akan membutuhkan waktu yang relatif lebih lama dibandingkan dengan program seleksi secara simultan. Uji keserempakan hasil atau sering disebut analisis multivariat sangat penting dalam program pemuliaan tanaman, untuk menyeleksi sejumlah tanaman yang digunakan sebagai tetua pada generasi berikutnya. Sifat-sifat itu diukur dan dievaluasi bersama. Pemuliaan tanaman dengan cara ini bertujuan mendapatkan keuntungan genetik yang sebesar-besarnya dalam waktu singkat (Johnson dan Wichern, 1982).

Kedelai merupakan tanaman dikotil semusim dengan percabangan sedikit, sistem perakaran akar tunggang yang membentuk akar-akar cabang yang tumbuh menyamping (horizontal) tidak jauh dari permukaan tanah, dan batang berkambium dengan tinggi 30-100 cm. Batang dapat membentuk 2 - 12 cabang, tetapi bila jarak antar tanaman rapat, cabang menjadi berkurang, atau tidak bercabang sama sekali. Kedelai dapat berubah penampilan menjadi tumbuhan setengah merambat dalam keadaan pencahayaan rendah.

Daun kedelai merupakan daun majemuk yang terdiri dari tiga helai anak daun dan umumnya berwarna hijau muda atau hijau kekuning-kuningan. Bentuk daun ada yang oval, juga ada yang segi tiga. Warna dan bentuk daun tergantung pada varietas masingmasing. Bunga kedelai disebut bunga kupu-kupu dan mempunyai dua mahkota dan dua kelopak bunga. Warna bunga putih bersih atau ungu muda (AAK, 1998).

Pertumbuhan kedelai baik pada daerah yang berhawa panas dan bercurah hujan 100 sampai $400 \mathrm{~mm}$ per bulan, oleh karena itu kedelai 
bayak ditanam di daerah berketinggian kurang dari 400 meter dari permukaan laut dengan suhu di dalam dan di permukaan tanah selama 30 sampai 40 hari sekitar $35^{\circ}$ sampai $40^{\circ}$ C (AAK, 1995). Suprapto (1999) menyatakan, iklim tropis cocok untuk pertumbuhan kedelai, karena kedelai menghendaki udara yang cukup panas. Pada umumnya pertumbuhan kedelai sangat ditentukan ketinggian tempat dan biasanya akan tumbuh baik pada ketinggian tidak lebih dari $500 \mathrm{~m}$ di atas permukaan laut. Antara suhu dan kelembaban harus selaras atau seimbang. Apabila tanah cukup lembab dan suhunya di atas $21^{\circ} \mathrm{C}$ biji kedelai berkecambah lebih cepat. Biasanya pada suhu ini biji kedelai akan tumbuh sekitar 5 hari setelah waktu tanam. Suhu yang tinggi dan kurangnya curah hujan pada saat menjelang panen memberikan banyak keuntungan.

Kedelai menghendaki kondisi tanah yang lembab, tetapi tidak becek. Kondisi ini dibutuhkan sejak benih ditanam hingga pengisian polong. Saat menjelang panen sebaiknya tanah dalam keadaan kering. Kekurangan air pada masa pertumbuhan akan menyebabkan tanaman kerdil, bahkan dapat menyebabkan kematian apabila kekeringan telah melampaui batas toleransi. Kekeringan pada masa pembungaan dan pengisian polong dapat menyebabkan kegagalan panen (Daniarti dan Najiati, 1998).
Hasil biji dikendalikan oleh banyak gen dan sangat peka terhadap pengaruh lingkungan. Pemuliaan untuk memperoleh varietas-varietas yang berdaya hasil tinggi tidaklah mudah. Hasil dapat didekati dari segi komponen hasil yang berupa jumlah tanaman per hektar, jumlah polong per tanaman, jumlah biji per polong dan berat 100 biji (Sumarno, 1985). Menurut Musa (1978) hasil biji setiap tanaman selain dipengaruhi oleh genotipe, juga dipengaruhi oleh budidaya dan keadaan lingkungan tumbuh yang lain seperti adanya perbedaan-perbedaan dalam kesuburan tanah dan cuaca dan komponen-komponen hasil tersebut berupa banyaknya buku subur pada batang utama, rata-rata banyaknya biji tiap polong dan ukuran biji, selain itu hasil juga dipengaruhi oleh sifat tinggi tanaman, banyaknya cabang, masa pembentukan polong dan pengisian biji serta persentase banyaknya biji aborsi.

Hasil olahan kedelai secara umum merupakan makanan yang bernilai gizi dan murah sehingga kedelai berperan besar di dalam peningkatan kesehatan dan gizi masyarakat (Yusuf, 1996). Sebagai makanan, kedelai sangat berhasiat bagi pertumbuhan dan menjaga kondisi sel-sel tubuh. Kedelai banyak mengandung unsur dan zatzat makanan penting seperti terlihat pada tabel berikut. 
Tabel 1. Kandungan Zat-zat Makanan pada Kedelai

\begin{tabular}{lcc}
\hline $\begin{array}{c}\text { Unsur Zat-Zat } \\
\text { Makanan }\end{array}$ & $\begin{array}{c}\text { Kedelai } \\
\text { Putih } \\
(\%)\end{array}$ & $\begin{array}{c}\text { Kedelai Hitam } \\
(\%)\end{array}$ \\
\hline Air & 13,75 & 14,05 \\
Protein & 41,00 & 40,40 \\
Lemak & 15,80 & 19,30 \\
Karbohidrat & 14,85 & 14,10 \\
Mineral & 5,25 & 5,25 \\
\hline
\end{tabular}

Sumber : AAK (1998)

\section{Di Indonesia kedelai} sebagian besar dikonsumsi dalam bentuk olahan seperti tempe, tahu, kecap dan susu nabati, sebagian kecil dikonsumsi langsung sebagai makanan ringan. Di samping itu juga dipergunakan sebagai pakan ternak. Kedelai merupakan sumber protein penting di Indonesia, kesadaran masyarakat akan pemenuhan gizi yang baik semakin meningkat baik kecukupan protein hewani maupun nabati. Protein hewani sampai saat ini masih mahal mengakibatkan masyarakat memilih alternatif protein nabati dengan harga yang murah dan terjangkau masyarakat luas (Mursito, 2003).

\section{Pemuliaan}

tanaman

merupakan seluruh usaha untuk perbaikan sifat tanaman. Sifat yang lebih baik yang dimaksud diantaranya: berproduksi lebih tinggi, lebih toleran terhadap berbagai faktor lingkungan , memiliki nilai gizi yang lebih baik, penanganan lebih mudah, dan lain sebagainya. Usaha untuk memperoleh varietas unggul memerlukan pengetahuan mengenai sifat-sifat tanaman yang hendak dimuliakan dan hubungan antara sifat-sifat tersebut (Mangoendidjoyo, 2003). Lebih lanjut Mangoendidjoyo mengatakan, varietas unggul merupakan faktor utama yang menentukan tinggi produksi. Pada dasarnya, suatu varietas unggul harus memenuhi beberapa persyaratan sebagai berikut: (1) mempunyai kemampuan berproduksi tinggi; (2) mempunyai kualitas hasil panen yang baik; dan (3) mempunyai kepastian hasil panen. Usaha untuk memperoleh suatu varietas unggul memerlukan pengetahuan mengenai sifat-sifat tanaman yang hendak dimuliakan dan hubungan antara sifat-sifat tersebut.

Tujuan akhir setiap program pemuliaan tanaman adalah untuk memperoleh tanaman yang dapat memberikan hasil sebesar-besarnya per satuan luas, bermutu dan memiliki sifat agronimik yang dikehendaki manusia. Pemuliaan tanaman seyogyanya memperhatikan dan mempertimbangkan selera konsumen, sehingga kegiatan ini haruslah bersifat progresif. Kegiatan 
pemuliaan tanaman memerlukan waktu panjang sehingga seorang pemulia tanaman harus mampu melihat kebutuhan pemakai untuk beberapa tahun mendatang.

Penggabungan semua sifat dalam kriteria kedelai unggul sangat sulit untuk dilakukan, sehingga tujuan pemuliaan harus dibatasi sesuai dengan kendala yang dihadapi daerah-daerah tertentu. Pada umumnya ada korelasi negatif antara umur genjah dengan hasil tinggi, sehingga perlu ada kompromi antara umur yang diinginkan dengan hasil yang ingin dicapai.

Menurut Hartatik (2007), agar program seleksi memberikan hasil yang diharapkan populasi tetua haruslah memiliki syarat sebagai berikut.

1. Dapat dihasilkan keragaman keturunan yang cukup besar. Hasil dapat diperoleh jika tetua persilangan cukup beragam.

2. Ukuran populasi cukup besar agar memberikan keleluasaan dalam pemilihan. Keragaman bahan tanaman dapat diperoleh dengan berbagai cara, antara lain : introduksi varietas baru, pemisahan hasil persilangan, mutasi buatan, poliploidi dan spesies liar.

Penampilan bentuk tanaman dikendalikan oleh sifat genetik tanaman di bawah pengaruh faktorfaktor lingkungan. Faktor lingkungan dan faktor genetik tetua khususnya kisaran variabilitas genetik sangat menentukan keberhasilan upaya mendapatkan varietas unggul. Semakin luas kisaran variabilitas genetik antar tetua, semakin besar peluang terbentuknya genotipe yang potensial. Menurut Hadiati (2003) dalam pembentukan varietas unggul tidak lepas dari pemilihan tetua untuk benih hibrida, dimana tetua harus memiliki karakter yang diinginkan, seperti berdaya hasil tinggi, mutu hasil tinggi, serta tahan terhadap hama, penyakit utama, juga harus mempunyai jarak genetik atau hubungan kekerabatan yang jauh agar tidak terjadi depresi in breeding.

Suatu varietas kedelai dikatakan unggul bila mempunyai kelebihan tertentu dibandingkan dengan varietas lokal yang telah ada. Keunggulan tersebut dapat berupa ketahanan terhadap lingkungan, hama dan penyakit, umur genjah, hasil yang lebih tinggi dan sifat agonomik lainnya. Sifat-sifat yang berkorelasi positif terhadap hasil biji antara lain adalah fase generatif yang panjang, umur dalam, protein rendah dan tahan rebah. Jumlah biji per polong dan jumlah biji per pohon mempunyai korelasi secara fenotipik positif terhadap hasil, namun ada korelasi nyata secara genetik (Yusuf, 1996).

Seleksi dengan berbagai metode merupakan salah satu kegiatan penting dalam pemuliaan tanaman. Keragaman sumber plasma nutfah akan memudahkan pemulia tanaman dalam menseleksi tanaman. 
Penampilan fenotipe suatu tanaman dipengaruhi oleh interaksi antara faktor genetik dan lingkungan.

program pemuliaan tanaman bermanfaat untuk menentukan arah seleksi yang dilaksanakan. Dengan mengetahui derajat dan pola hubungan antar komponen hasil dan hasil, maka dapat diketahui kegunaan dari masing-masing komponen hasil dan hasil, yang selanjutnya dapat dijadikan dasar dalam menentukan program seleksi yang akan dilakukan (Yusuf, 1996).

Secara mutlak tidak dapat diketahui apakah suatu sifat ditentukan oleh faktor genotipe atau faktor lingkungan. Faktor genotipe tidak akan menampakkan sifat yang dibawa kecuali berada dalam lingkungan yang sesuai. Keragaman yang ada pada populasi suatu tanaman disebabkan oleh faktor genotipe atau lingkungan. Penentuan faktor mana yang lebih berperan terhadap keragaman populasi tanaman, maka didefinisikan apa yang disebut heritabilitas.

$$
\text { Istilah heritabilitas }\left(\mathrm{h}^{2}\right)
$$

dimaksud sebagai proporsi ragam genotipe terhadap ragam fenotipe yang dinyatakan dengan persentase. Nilai ini berguna untuk mengetahui sampai sejauh mana pengaruh genotipe dan pengaruh lingkungan terhadap penampakkan fenotipe suatu sifat. Heritabilitas sama dengan $100 \%$ bilamana tidak terdapat ragam lingkungan. Bila ragam lingkungan membesar, maka nilai heritabilitas akan menurun (Brewbaker, 1983). Taksiran heritabilitas digunakan sebagai langkah awal pada pekerjaan seleksi terhadap populasi yang bersegregasi. Populasi tanaman dengan sifat-sifat heritabilitas tinggi memungkinkan dilakukan seleksi, sebaliknya dengan heritabilitas rendah masih harus dilihat tingkat rendahnya, yakni bila terlalu rendah (hampir mendekati nol), berarti tidak akan banyak berguna bagi pekerjaan seleksi tersebut. Menurut Makmur (1985), besaran nilai heritabilitas dapat digunakan untuk menentukan apakah seleksi yang dilakukan terhadap suatu sifat dari populasi tanaman pada lingkungan tertentu mengalami kemajuan genetik atau tidak.

Korelasi diantara sifat-sifat dapat disebabkan oleh pengaruh lingkungan ataupun pengaruh genetik. Suatu pengetahuan tentang besar dan tanda dari koefesien korelasi genetik diantara sifat-sifat dapat digunakan sebagai kriteria seleksi. Perkiraan ini berguna dalam menduga apakah seleksi untuk sifat tertentu akan memberi pengaruh menguntungkan atau tidak pada sifat yang lain (Miftahorrachman et al, 2000 dan Warwick et al. 1990).

Korelasi merupakan analisis sifat-sifat tanaman, tetapi pada umumnya korelasi tidak memperhatikan faktor sebab dan akibat. Korelasi hanya memperhatikan faktor sifat tersebut mempunyai perubahan-perubahan yang masing-masing dicari 
kerapatannya (Singh dan Chaudhary, 1979).

\section{Analisis korelasi berkenaan dengan upaya mempelajari} keeratan hubungan antar variabel. Dengan demikian dalam analisis korelasi tidak diperlukan pembeda antara variabel tergantung dan variabel bebas. Sehingga analisis korelasi dapat dipergunakan untuk menentukan besarnya keeratan hubungan antara (a) variabel tergantung dengan variabel tergantung, (b) variabel tergantung dengan variabel bebas, dan (c) variabel bebas dengan variabel bebas (Solimun, 2001).

Menurut Soemartono et al. (1992) ada beberapa jenis korelasi antar sifat tanaman, yaitu : 1) korelasi genetik atau korelasi genotipe adalah korelasi antar sifat yang hanya ditimbulkan oleh faktor genetik total, 2) korelasi genetik additif atau korelasi additif adalah korelasi antar sifat yang hanya ditimbulkan oleh faktor genetik additif, 3) korelasi lingkungan adalah korelasi antara dua sifat pada suatu tanaman karena adanya perubahan lingkungan. Misalnya korelasi lingkungan positif bisa terjadi antara tinggi tanaman dan tinggi tongkol pada tanaman jagung, karena perubahan lingkungan mikro yang memperbaiki tinggi tanaman juga memperbaiki tinggi tongkol. Selanjutnya dinyatakan oleh Soemartono et al. (1992), bahwa korelasi lebih banyak digunakan pada jenis tanaman menyerbuk sendiri yang homosigot atau jenis tanaman yang apomiktik. Sedangkan korelasi additif lebih banyak digunakan pada tanaman menyerbuk silang. Korelasi additif penting dalam program seleksi, karena pengaruh additif dapat diubah dengan seleksi.

Penaksiran keeratan hubungan antar sifat menurut Solimun (2001), dinyatakan dalam koefisien korelasi, yang dilambangkan dengan $\mathrm{p}$ (dibaca rho, untuk populasi) dan $\mathrm{r}$ (untuk sampel). Besarnya koefisien korelasi berkisar antara -1 sampai +1 , atau dapat ditulis dengan $-1 \leq \mathrm{r} \leq+1$. Terjadi hubungan yang erat positif, jika $r$ mendekati +1 dan erat jika $r$ mendekati -1 , dikatakan tidak ada hubungan jika r mendekati 0 (nol).

$$
\text { Pada bidang Pertanian }
$$
pengetahuan mengenai korelasi antara sifat-sifat agronomi suatu tanaman dengan daya hasil memainkan peranan penting untuk seleksi simultan pada beberapa sifat (Musa, 1978). Sedangkan menurut Singh dan Chandhary (1979); Warwick et al. (1990), korelasi merupakan analisis untuk mengukur kerapatan hubungan yang terjadi antara sifat tanaman yang satu dengan sifat yang lainnya. Misal terdapat $r_{x y}=0.98$, maka dapat dikatakan bahwa antara sifat $\mathrm{X}$ dan $\mathrm{Y}$ terdapat hubungan yang erat positif, yaitu kenaikan nilai $\mathrm{X}$ akan diikuti oleh kenaikan nilai Y hampir secara proporsional. Dengan 
demikian dapat dikatakan bahwa koefisien korelasi dapat digunakan untuk menilai perubahan suatu sifat/variabel berdasarkan perubahan variabel lain. Akan tetapi dalam penelitian tersebut hanya dapat memberikan prakiraan (prediksi) yang bersifat kualitatif.

\section{Somaatmadja}

menyatakan bahwa korelasi genotipik berguna untuk mengetahui apakah dua sifat dapat atau tidak diperbaiki bersama-sama, dimana sifat-sifat yang berkorelasi positif nyata dapat diperbaiki secara bersamaan. Sedangkan (Astika, 1991 dalam Poerwoko, 1995) menyatakan bahwa pengetahuan adanya korelasi antara sifat merupakan hal yang sangat penting dalam program pemuliaan tanaman, karena untuk memilih suatu bahan tanaman unggul diperlukan seleksi dua atau tiga sifat secara bersama-sama. Apabila diketahui adanya korelasi yang erat antar sifat maka pemilihan sifat tertentu secara tidak langsung telah memilih sifat lain yang diperlukan dalam usaha memperoleh bahan tanaman unggul.

Menurut Soermartono et al. (1992) manfaat korelasi antar sifat selain untuk memprediksi correlated respons, juga penting dalam penerapan seleksi tak langsung (indirect selection). Cara ini diterapkan apabila sifat primer atau sifat I sulit diukur dan dievaluasi. Sedang sifat II yang berkorelasi dengan I mudah diukur dan dievaluasi atau sifat I heritabilitasnya rendah dan sifat II heritabilitasnya tinggi.

Analisis lintas (path analysis) merupakan suatu teknik analisis statistika yang dikembangkan dari analisis regresi berganda. Teknik ini dikenal juga sebagai analisis lintas atau analisis lintasan. Teknik ini pertama kali diperkenalkan oleh Sewall Wright pada tahun 1934 sebagai alat untuk mengkaji hubungan antar peubah dalam produksi ternak, namun penerapannya sekarang meluas ke bidang-bidang lain, seperti genetika terapan dan ekonomi.

Secara matematis, analisis ini tidak lain adalah analisis regresi berganda terhadap data yang dibakukan. Dengan demikian, perangkat lunak statistika yang mampu melakukan analisis regresi berganda dapat pula dipakai untuk analisis lintas. Subjek utama analisis ini adalah peubah-peubah yang saling berkorelasi. Analisis ini mendasarkan pada model hubungan antar peubah yang ditentukan sebelumnya oleh peneliti. Penentuan model didasarkan pada hipotesis mengenai berbagai peubah yang diamati.

Analisis lintas didasarkan pada analisis korelasi antar variabel. Koefisien korelasi dari dua faktor dapat dijadikan ukuran sejauh mana derajat keeratan hubungan kedua faktor tersebut. Perlu ditegaskan disini bahwa analisis korelasi berbeda dengan analisis regresi meskipun keduanya tidak dapat 
dipisahkan. Dalam analisis regresi, dilihat hubungan pengaruh antar variabel bebas (variabel peramal) dan variabel respon (variabel tak bebas), dan terdapat ketergantungan antar dua variabel tersebut, sehingga kedua variabel yang dikorelasikan mempunyai kedudukan yang sama (Gaspersz, 1991). Lebih lanjut Gaspersz menyatakan bahwa analisis lintas sangat bermanfaat untuk mengetahui pola hubungan kausal antar faktor (antar variabel peramal) terhadap peubah respon. Melalui model lintasan, dapat diukur pengaruh langsung dari suatu faktor terhadap respon hasil, demikian pula diketahui pengaruh tidak langsung faktor tersebut.

Jika hubungan sebab dan akibat didefinisikan dengan baik maka dapat digambarkan sistem keseluruhan dari peubah dalam sebuah diagram yang disebut PathDiagram.

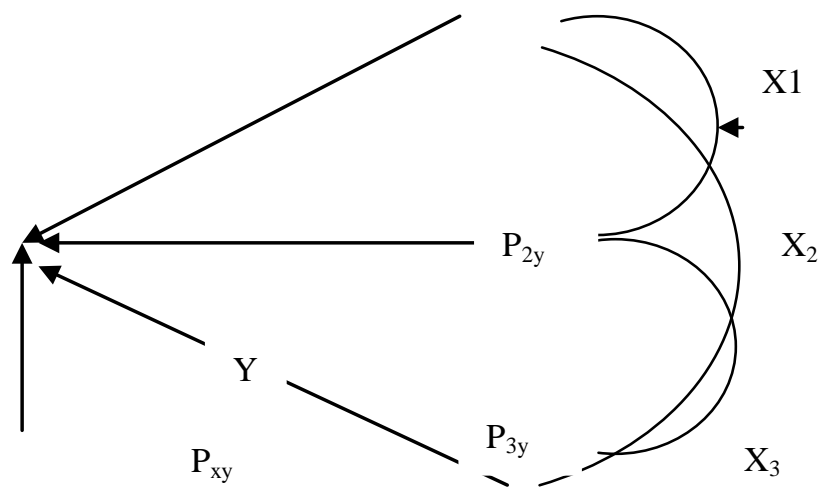

Gambar 1. Hubungan Sebab Akibat Dari Analisis Lintas

Penjabaran teoritisnya adalah sebagai berikut :

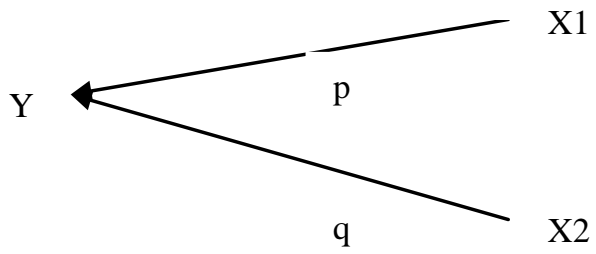

Gambar 2. Diagram Lintas 
$Y=X_{1}+X_{2}$

Korelasi $X_{1}$ dan $Y$ dapat dijabarkan menjadi :

1. Disebabkan pengaruh langsung $X_{1}$ terhadap $Y\left(P_{1 y}\right)$

2. Disebabkan pengaruh tidak langsung $X_{1}$ terhadap $Y$ $X_{2}, r\left(X_{1}, X_{2}\right) P_{2 y}$

3. Disebabkan pengaruh tidak langsung $X_{1}$ terhadap $Y$ melalui $X_{3}, r\left(X_{1}, X_{3}\right) P_{3 y}$

Analisis multivariat adalah salah satu cabang statistik yang berupa ringkasan, gambaran dan keterangan sampel dari suatu populasi dimana perubahan unsurunsur hasil diukur lebih dari satu sifat atau karakter (Kramer, 1982). Dalam analisis ragam multivariat dipertimbangkan adanya ketergantungan diantara peubahpeubah respon, sedangkan dalam analisis ragam univariat hal itu tidak menjadi perhatian utama karena pada dasarnya dianggap bahwa peubah respon itu saling bebas satu sama lain, sehingga pengkajian struktur keragaman hanya dilakukan terhadap setiap peubah respon secara terpisah (Gaspers, 1995).

Prinsip multivariat adalah perluasan dari univariat dan bivariat, dimana jika univariat atau bivariat hanya menghitung maksimal dua peubah. Dalam praktek multivariat semua peubah dianalis secara simultan atau bersamaan. Perbedaan tersebut merupakan keunggulan bagi multivariat. Hal ini disebabkan banyaknya percobaan atau fenomena yang secara alamiah melibatkan banyak peubah (Santoso, 2003).

Seleksi merupakan bagian penting dari program pemuliaan tanaman untuk memperbesar peluang mendapatkan genotipe yang unggul. Hal ini juga berlaku untuk pemuliaan tanaman kedelai. Pengujian perlu dilakukan sebanyak mungkin pada galur-galur kedelai terpilih, sehingga didapatkan galurgalur kedelai yang berdaya hasil tinggi (Pinaria et al., 1995).

\section{METODE PENELITIAN}

Penelitian dilaksanakan di Kebun Percobaan Balai Percobaan Tanaman Kacang-kacangan dan Umbi-umbian yang berlokasi di Desa Klompang Timur Kecamatan Pakong Kabupaten Pamekasan Propinsi Jawa timur. Wilayah ini terletak pada ketinggian $\pm 40 \mathrm{dpl}$, posisi $7^{\circ} 21^{\prime}-7^{\circ} 31^{\prime}$ lintang selatan dan $110^{\circ} 10^{\prime}-111^{\circ} 40^{\prime}$ bujur timur, beriklim tropis, dengan curah hujan 1.715,37 mm/tahun. Percobaan dilaksanakan mulai bulan April sampai dengan September 2008.

\section{Bahan dan Metode}

Peneitian dilaksanakan dengan menggunakan Rancangan Acak Kelompok dua belas genotipe tiga ulangan. Model linier untuk RAK menurut Sudjana (1989), adalah sebagai berikut :

$$
\begin{aligned}
& \mathrm{Y}_{\mathrm{ij}}=\mu+\sigma_{\mathrm{i}}+\beta_{\mathrm{j}}+\varepsilon_{\mathrm{ij}} \\
& \text { dalam hal ini }
\end{aligned}
$$


$\mathrm{Y}_{\mathrm{ij}}=$ nilai pengamatan dari perlakuan ke-i dalam kelompok ke-j

$\mu=$ nilai tengah populasi

$\sigma_{\mathrm{i}}=$ pengaruh aditif dari

genotipe ke-i $\beta_{\mathrm{j}}=$ pengaruh aditif dari blok ke-j

$\varepsilon_{\mathrm{ij}}=$ pengaruh galat percobaan dari perlakuan ke-i pada ulangan ke-j

Tabel 2. Analisis Ragam Rancangan Acak Kelompok

\begin{tabular}{|c|c|c|c|c|}
\hline $\begin{array}{c}\text { Sumber } \\
\text { Keragaman }\end{array}$ & DB & JK & $\mathrm{KT}$ & $\begin{array}{c}\text { Nilai Harapan Kuadrat } \\
\text { Tengah }\end{array}$ \\
\hline Ulangan & 2 & JKU & KTU & \multirow{4}{*}{$\begin{array}{c}\sigma_{\mathrm{e}}^{2}+\mathrm{g} \sigma_{\mathrm{u}}^{2} \\
\sigma_{\mathrm{e}}^{2}+\mathrm{u} \sigma_{\mathrm{g}}^{2} \\
\sigma_{e}^{2}\end{array}$} \\
\hline Genotipe & 11 & JKG & KTG & \\
\hline \multirow[t]{2}{*}{ Galat } & 22 & JKE & KTE & \\
\hline & & & & \\
\hline Total & 35 & - & - & - \\
\hline Keterangan : & $\begin{array}{l}\mathrm{u}=\mathrm{ul} \\
\mathrm{g}=\mathrm{ge} \\
\mathrm{f}=\mathrm{fen}\end{array}$ & & & \\
\hline
\end{tabular}

Berdasarkan nilai harapan kuadrat tengah, maka dapat dihitung.

Ragam Genetik $=\sigma_{g}^{2}=$ $\frac{M S_{g}-M S_{e}}{u}=\frac{\left(\sigma_{e}^{2}+u \sigma_{g}^{2}\right)-\sigma_{e}^{2}}{u}$

Ragam Lingkungan = $\sigma_{e}^{2}=M S_{e}$

$>$ Ragam Fenotipe $=\sigma_{f}^{2}$ $=\sigma_{g}^{2}+\sigma_{e}^{2}$
$>$ Peragam Genotipe = $\left(\sigma_{g}^{2}\right)=\frac{\mathrm{KTg}-\mathrm{KTe}}{\mathrm{u}}$

Peragam Lingkungan $=$ $\left(\sigma_{e}^{2}\right)=\mathrm{KTe}$

Peragam Fenotipe = $\left(\sigma_{f}^{2}\right)=\sigma_{g}^{2}+\sigma_{e}^{2}$

Koefisien

Keragaman Genotipik (KKg) dihitung dengan rumus: 


$$
\mathrm{KKg}=\frac{\sqrt{\sigma_{g}^{2}}}{\bar{X}} \mathrm{x}
$$

Sedang Koefisien Keragaman

Fenotipik (KKf) dihitung

dengan rumus:

$$
\begin{aligned}
& \text { KKf }=\frac{\sqrt{\sigma_{p}^{2}}}{\bar{X}} \mathrm{x} \\
& 100 \% \\
& \text { dalam hal ini: } \bar{X} \\
& =\text { rata-rata umum }
\end{aligned}
$$

Berdasarkan nilai ragam genetik, fenotipik, dan lingkungan, maka dapat dihitung nilai heritabilitasnya. Pendugaan nilai heritabilitas dalam penelitian ini digunakan rumus heritabilitas dalam arti luas (Allard, 1988), yaitu :

$$
h^{2}=\left(\frac{\sigma_{g}^{2}}{\sigma_{p}^{2}}\right) \times 100 \%
$$

dalam hal ini :

$$
\begin{aligned}
\mathrm{h}^{2} & =\text { nilai heritabilitas } \\
\sigma_{g}^{2} & =\text { ragam genotipe } \\
\sigma_{p}^{2} & =\text { ragam fenotype }
\end{aligned}
$$

Stansfield (1969) dan Whirter (1979) dalam Hartatik (2007) menyatakan bahwa nilai heritabilitas dapat dikategorikan menjadi tiga kriteria yaitu tinggi, sedang dan rendah. Termasuk dalam kategori tinggi bila nilai heritabilitas lebih dari 50 persen, kriteria sedang bila nilai heritabilitasnya antara 20 persen sampai dengan 50 persen dan kriteria rendah jika nilai heritabilitasnya kurang dari 20 persen.

\section{Korelasi Genetik}

Untuk mengetahui besarnya nilai koefisien korelasi genotipik antara dua karakter agronomis kedelai dihitung berdasarkan rumus Singh and Chaudhary (1979) sebagai berikut.

$$
\mathrm{Rx} 1 \mathrm{x} 2=\frac{\operatorname{cov}_{\mathrm{x} 1 \mathrm{x} 2}}{\sqrt{\sigma_{\mathrm{gx} 1 . \sigma \mathrm{gx} 2}^{2}}}
$$

$\mathrm{R}_{\mathrm{x} 1 \times 2}=$ korelasi genotipik sifat $\mathrm{X}_{1}$ dan $\mathrm{X}_{2}$

$\operatorname{Cov}_{\mathrm{x} 1 \times 2}=$ peragam genotipe antara sifat $\mathrm{X}_{1}$ dan $\mathrm{X}_{2}$

$\sigma_{g}^{2} 1=$ ragam genetik sifat

$\mathrm{X}_{1}$

$\sigma_{g}^{2} \mathrm{X} 2 \quad=$ ragam genetik sifat

$\mathrm{X}_{2}$

\section{Analisis Lintas}

Hasil (Yield) merupakan sumbangan dari $\mathrm{X}_{1}, \mathrm{X}_{2}$ dan $\mathrm{X}_{3}$ serta beberapa faktor lain yang disumbangkan sebagai $\mathrm{R}$ (Resdual effect). $\mathrm{X}_{1}, \mathrm{X}_{2}$ dan $\mathrm{X}_{3}$ berkorelasi. $\mathrm{P}_{1 \mathrm{y}}, \mathrm{P}_{2 \mathrm{y}}$ dan $\mathrm{P}_{3 \mathrm{y}}$ adalah koefisien lintas.

Sebagai petunjuk untuk interpretasi hasil dari analisis lintas, 
Singh dan Chaudhary (1979)

1. Jika koefisien korelasi antara faktor penyebab dan faktor akibat nilainya hampir sama dengan pengaruh langsungnya (P), maka korelasi tersebut menunjukkan hubungan yang benar,

2. dan seleksi melalui pengaruh langsungnya akan efektif,

3. Jika koefisien korelasinya positif, tetapi pengaruh langsungnya negatif atau dapat diabaikan, maka pengaruhpengaruh tidak langsung mengemukakan tiga kriteria berikut. merupakan penyebab korelasi. Dalam hal demikian, seleksi melalui pengaruh tidak langsungnya harus dipertimbangkan,

4. Koefisien korelasinya mungkin negatif, tetapi pengaruh langsungnya positif dan tinggi. Dalam keadaan demikian, dilakukan seleksi simultan bebas, yaitu dengan cara mengabaikan pengaruhpengaruh yang tidak berkenan.

Tabel 3. Rancangan Acak Kelompok Berdasarkan Analisis Multivarat

\begin{tabular}{|c|c|c|c|c|c|c|}
\hline SK & $\mathrm{Db}$ & JK & up, m, n & $\mathrm{P}$ & $\mathrm{m}$ & $\mathrm{n}$ \\
\hline \multirow[t]{2}{*}{ Genotipe } & 11 & $\mathrm{JKg}$ & $|J K e|$ & $\mathrm{P}$ & (g-1) & $(\mathrm{g}-1)(\mathrm{u}-1)$ \\
\hline & & & $J K g+J K e \mid$ & & & \\
\hline \multirow[t]{2}{*}{ Ulangan } & 2 & Jku & $|J K e|$ & & & \\
\hline & & & $J K u+J K e$ & & & \\
\hline Galat & 22 & JKe & & & & \\
\hline Total & 35 & $\mathrm{JKt}$ & & & & \\
\hline
\end{tabular}

\section{Analisis Multivariat}

Menurut Marissan

(1976), model matematis data menggunakan mutlivariat adalah sebagai berikut.

$$
\begin{aligned}
& \mathrm{X}_{i j k}=\mu_{\mathrm{k}}+\alpha_{i k}+\beta_{j k}+ \\
& \varepsilon_{i j k} \\
& \text { (genotipe) } \\
& =1,2,3, \ldots 12 \\
& =1,2,3 \text { (ulangan) }
\end{aligned}
$$

$$
\mathrm{k} \text { agronomik) }=1,2,3 \ldots \text { (sifat }
$$

dalam hal ini :

$\mathrm{X}_{i j k}=$ pengamatan pada sifat ke-

$\mathrm{k}$, genotipe ke- 1 , ulangan ke- $\mathrm{j}$

$\mu_{k}=$ harga rata-rata dari sifat

ke-k

$\alpha_{i k} \quad=$ pengaruh genotipe ke-i

terhadap sifat ke-k

$\beta_{j k}=$ pengaruh ulangan ke-j

terhadap sifat ke-k 
$\varepsilon_{i j k}=$ pengaruh sisa galat dari pengamatan sifat ke-k, genotipe ke-i, ul. ke-j

Menurut Srivasta dan Carter (1983), Model multivarat dari rancangan acak kelompok adalah sebagai berikut.

Untuk menguji signifikasi dalam seleksi simultan digunakan rumus yang dikemukakan oleh Kramer (1982), yaitu:

$$
U=\frac{|E|}{|E+H|}
$$

dalam hal ini :

$|\mathrm{E}|=$ determinan matriks penguji/matriks galat (pengaruh sisa).

$|\mathrm{E}+\mathrm{H}|=$ determinan matriks JK genotipe $(\mathrm{H})$ dan jumlah kuadrat galat.

yang selanjutnya dibandingkan dengan table distribusi U. Hasil uji menunjukkan nilai yang berbeda nyata jika U hitung lebih kecil dari U tabel.

\section{Pendugaan Kemajuan Respon}

\section{Daya Hasil}

Besarnya nilai duga kemajuan respon daya hasil dapat dihitung berdasarkan rumus yang dikemukakan oleh Singh dan Chaudhry (1979), yaitu sebagai berikut. $\mathrm{R}=(\mathrm{Z} / \mathrm{v}) \times \mathrm{W} /\left(\mathrm{V}_{\mathrm{p}}\right)^{1 / 2}$

dalam hal ini:

$\mathrm{R}=$ Nilai duga kemajuan respon daya hasil
$\mathrm{Z} / \mathrm{Vv}=$ Diferensial seleksi yang telah dibakukan

$\begin{array}{ll}\mathrm{W} & =\sum \sum \mathrm{a}_{\mathrm{i}} \mathrm{G}_{\mathrm{ij}} \mathrm{b}_{\mathrm{j}} \\ \mathrm{a}_{\mathrm{i}} & =\text { Bobot ekonomi nisbi } \\ \mathrm{b}_{\mathrm{i}} & =\text { Koefisien regresi } \\ \mathrm{G}_{\mathrm{ij}} & =\text { Matrik varian- }\end{array}$

kovariann genetik

$\mathrm{V}_{\mathrm{p}} \quad=\sum \sum \mathrm{b}_{\mathrm{i}} \mathrm{G}_{\mathrm{ijj}} \mathrm{b}_{\mathrm{j}}$

$\mathrm{P}_{\mathrm{ij}} \quad=$ Matrik varian-

kovarian fenotipik

Besarnya nilai duga kemajuan respon daya hasil parsial, yaitu kemajuan respon daya hasil berat biji per petak (Kgpy), dapat dihitung berdasarkan rumus yang dikemukakan oleh Wricke dan Weber (1986) dalam Poerwoko (1995), yaitu sebagai berikut:

$$
\begin{aligned}
& \mathrm{i} \frac{b_{i} c_{y}}{\sqrt{b_{i} P b V(y)}} \\
& \mathrm{i}=\frac{G_{i} \cdot b_{j}}{\sqrt{(b i P i j)\left(\sigma_{g y}^{2}\right)}}
\end{aligned}
$$$$
\text { KGpy = }
$$

dalam hal ini:

$$
\begin{aligned}
& \text { i } \quad=\text { Intensitas seleksi (5\%) } \\
& \mathrm{Gi} \quad=\text { Matrik varian- } \\
& \text { kovarians genetik pada baris ke-i } \\
& \text { bj = Koefisien regresi pada } \\
& \text { pada kolom ke-j } \\
& \text { pij = Matrik varian- } \\
& \text { kovarians fenotipik } \\
& \text { bi = Koefisien regresi pada }
\end{aligned}
$$


$\sigma_{\mathrm{gy}} \quad=$ Varian berat biji per

petak

\section{Parameter}

Pengamatan meliputi sifatsifat agronomi sebagai berikut.

1. Berat biji per tanaman (g),

2. Berat 100 biji (g) yaitu berat biji bernas per tanaman,

3. Jumlah biji per tanaman, yaitu jumlah biji bernas per tanaman,
4. Jumlah polong per tanaman, yaitu jumlah semua polong yang terdapat pada tanaman tanpa memperhatikan polong isi satu, dua, tiga, dan seterusnya,

5. Umur matang panen (hari), dihitung mulai dari saat tanamn sampai dengan menjelang tanaman dipanen,

6. Berat biji per petak (g).

Tabel 4. Rangkuman Nilai Kuadrat Tengah Pada Semua Parameter yang Diamati

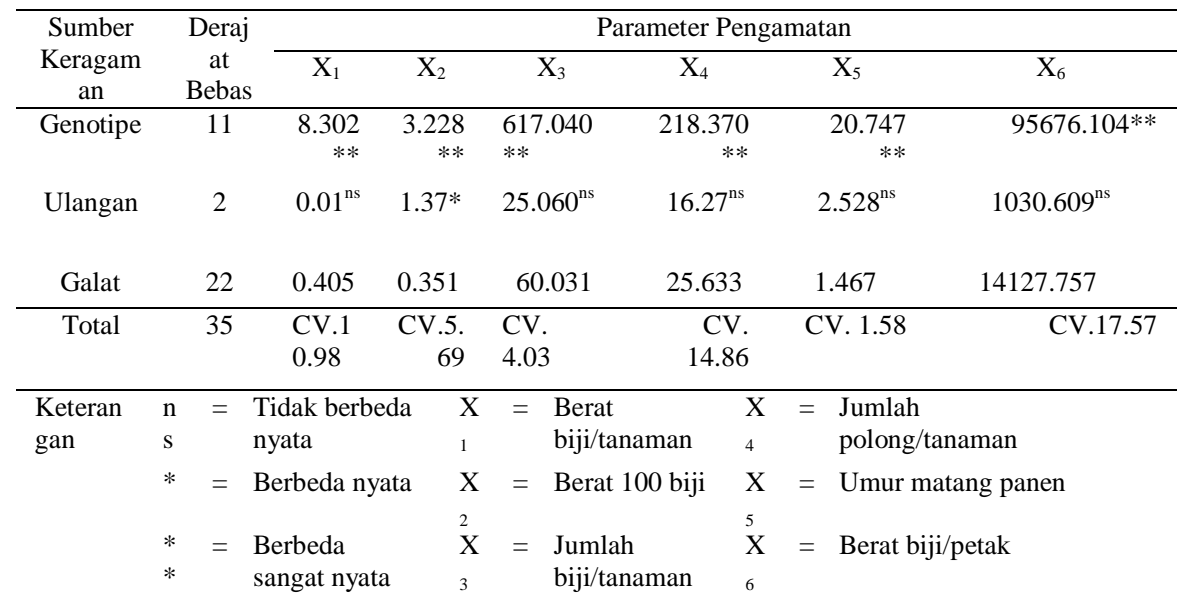

\section{HASIL DAN PEMBAHASAN}

Berdasarkan

analisis ragam yang dilakukan pada beberapa sifat yang diamati, ragam nilai kudrat tengah seperti ditampilkan pada tabel berikut. Berdasarkan Tabel 4, genotipe yang dipergunakan menunjukkan 
perbedaan yang sangat nyata pada seluruh sifat yang diamati. Perbedaan ini menunjukkan bahwa faktor genetik dari masing-masing genotipe kedelai yang diamati memiliki susunan genetik yang berbeda. Menurut Dixit et al (1969) jika nilai kuadrat tengah menunjukkan perbedaan sangat nyata maka seleksi yang dilakukan terhadap karakter akan lebih efektif.

Fenotipe suatu individu merupakan hasil ekspresi suatu gen yang berinteraksi dengan gen lain dan atau lingkungannya. Sifat-sifat yang berbeda dari suatu individu menggambarkan perbedaan susunan genetiknya (Hartatik, 2008). Perbedaan yang sangat nyata pada dua belas genotipe kedelai dari enam karakter yang diamati, diduga kuat disebabkan oleh genotipe yang berbeda atau tidak sama, pengaruh genetik dalam memunculkan enam karakter tersebut sangat kuat dibandingkan lingkungan. Besarnya pengaruh genetik dan pengaruh lingkungan terhadap fenotipe dapat kita lihat dari perhitungan nilai koefisien keragaman genotipe, fenotipe, lingkungan dan nilai heritabilitasnya.

Nilai Coefisien of Variability (CV) menunjukkan ukuran penyimpangan galat dari nilai rata-rata yang seharusnya mempunyai nilai yang seragam. Nilai CV juga menunjukkan tingkat ketelitian perlakuan yang dibandingkan dan dapat digunakan sebagai petunjuk terhadap tingkat kepercayaan suatu percobaan. Tingginya nilai CV menunjukkan semakin rendah tingkat kepercayaan dari hasil percobaan tersebut. Jika dilihat dari nilai CV pada Tabel 2, nilai CV relatif masih kecil, dengan kisaran $1.58 \%$ sampai 17.57 persen. Gomez dan Gomez (1984) menyatakan, bahwa pada umumnya nilai CV di atas $20 \%$ dapat dianggap tinggi.

\section{Koefisien Keragaman, Ragam Genotipe, Ragam Fenotipe dan Ragam}

\section{Lingkungan}

Besar kecilnya nilai keragaman genetik dapat ditentukan berdasarkan nilai koefisien keragaman genetiknya. Nilai keragaman merupakan tolak ukur keragaman karakter yang diamati dalam populasi yang dipelajari. Berdasarkan kriteria Miligan et al. (1996) dalam Sudarmadji et al. (2007), koefisien keragaman genetik dibagi dalam tiga kategori, yaitu: (1) Besar, bila koefisien keragam genetik bernilai lebih besar sama dengan 14.5\%, (2) sedang, bila koefisien keragam genetik bernilai antara 5\% hingga $14.5 \%$, dan (3) kecil, bila koefisien keragam genetik bernilai di bawah 5 persen.

Ragam genotipe, fenotipe dan lingkungan serta koefisien keragaman masing-masing sifat tanaman kedelai disajikan pada Tabel 5 sebagai berikut. 
Tabel 5. Ragam Genetipe, Fenotipe dan Lingkungan serta Koefisien Keragaman pada Parameter Pengamatan

\begin{tabular}{|c|c|c|c|c|c|c|c|}
\hline \multirow[t]{3}{*}{ No. } & \multirow{3}{*}{$\begin{array}{l}\text { Parameter } \\
\text { Pengamatan }\end{array}$} & \multicolumn{6}{|c|}{ Ragam $\left(\sigma^{2}\right)$ dan Koefisien Keragaman } \\
\hline & & $\overline{\sigma_{g}^{2}}$ & $\left(\mathrm{KK}_{\mathrm{g}}\right)$ & $\sigma_{f}^{2}$ & $\left(\mathrm{KK}_{\mathrm{f}}\right)$ & $\sigma_{e}^{2}$ & ( \\
\hline & & \multicolumn{6}{|l|}{$\left.\mathrm{KK}_{\mathrm{e}}\right)$} \\
\hline 1. & Berat biji per tanaman & 2.632 & 27.99 & 3.037 & 30.06 & 0.405 & 10.98 \\
\hline 2. & Berat 100 biji & 0.959 & 9.41 & 1.310 & 11.00 & 0.351 & 5.69 \\
\hline 3. & Jumlah biji per tanaman & 185.669 & 24.67 & 245.701 & 28.39 & 60.031 & 14.03 \\
\hline 4. & $\begin{array}{l}\text { Jumlah polong per } \\
\text { tanaman }\end{array}$ & 64.246 & 23.53 & 89.879 & 27.83 & 25.633 & 14.86 \\
\hline 5. & Umur panen & 6.427 & 3.30 & 7.894 & 3.65 & 1.467 & 1.58 \\
\hline 6. & Berat biji per petak & $\begin{array}{r}27182.7 \\
82\end{array}$ & 24.38 & 41310.539 & 30.05 & 14127.757 & 17.57 \\
\hline
\end{tabular}

Berdasarkan Tabel 5, nilai koefisien keragaman genotipe berkisar $3.30 \%$ hingga $27.99 \%$ dengan kriteria kecil sampai besar, koefisien keragaman fenotipe berkisar antara $3.65 \%$ hingga $30.06 \%$ dengan kriteria kecil hingga sedang. Nilai koefisien keragaman lingkungan secara umum memiliki kriteria kecil hingga sedang, kecuali pada parameter jumlah biji per tanaman dan berat biji per petak, namun nilainya masih di bawah koefisien keragaman genotipenya.

Ragam dan koefisien keragaman genotipe, fenotipe dan lingkungan untuk masing-masing parameter pengamatan menunjukkan ragam genotipe memiliki ragam yang lebih besar daripada ragam lingkungan. Hal ini berarti bahwa semua genotipe yang digunakan dalam percobaan ini memiliki rentang keragaman yang besar dan sifat-sifat agronomi tersebut banyak dipengaruhi oleh faktor genetik daripada faktor lingkungan. Nilai ragam genetik lebih besar daripada ragam lingkungan berarti genotipe memiliki respon yang baik terhadap usaha perbaikan sifat karena nilai ragam genetik pada akhirnya akan memberikan sumbangan yang besar terhadap sifat yang terdapat pada ragam fenotipe yang akan menyebabkan kenampakan pada tanaman. Keragaman genetik suatu popolasi yang berarti peluang untuk mewariskan sifat-sifat yang diinginkan pada generasi selanjutnya akan semakin besar.

$$
\text { Rasyat (1996) dalam }
$$

Sudarmadji et al (2007) menyatakan jika nilai koefisien keragaman genetik tinggi, maka faktor genetik akan berpengaruh besar pada penampilan sifat tersebut. Komponen-komponen dengan 
koefisien keragaman genetik kategori tinggi tersebut sangat penting dalam mendukung suatu varietas untuk dipilih sebagai varietas anjuran, atau bahkan diseleksi untuk pemilihan tetua dalam pembentukan varietas baru. Lebih lanjut Sudarmadji et al (2007) menyatakan, koefisien keragaman genetik yang tinggi pada suatu sifat menunjukkan bahwa sebagian besar sifat yang diamati tersebut memperlihatkan peluang terhadap usaha-usaha perbaikan yang efektif melalui seleksi dengan memberikan keleluasaan dalam memilih genotipe-genotipe yang diinginkan, melalui penggalian kombinasi genetik-genetik baru.

Menurut Makmur (1988), jika keragaman sebagai akibat faktor lingkungan dan keragaman genetik umumnya berinteraksi satu dengan yang lainnya dalam mempengaruhi penampilan fenotipe tanaman.
Koefisien keragaman pada suatu percobaan dapat digunakan sebagai petunjuk untuk mengetahui apakah suatu populasi menunjukkan homogen atau heterogen. Alnopri (2004) menyatakan bahwa, variabilitas yang luas merupakan salah satu syarat seleksi terhadap karakter yang diinginkan.

\section{Pendugaan Nilai Heritabilitas}

Heritabilitas merupakan
ukuran apakah yang menentukan
perbedaan penampilan suatu karakter
lebih disebabkan oleh faktor genetik
atau lingkungan, juga merupakan
ukuran kenampakan akhir suatu
tanaman yang mengindikasikan
bahwa penampilan tanaman
disebabkan oleh genetik, lingkungan
atau keduanya berpengaruh secara
bersama-sama. Heritabilitas dari sifat
sifat yang diamati ditunjukkan pada
Tabel 6

Tabel 6. Heritabilitas pada Masing-Masing Parameter Pengamatan

\begin{tabular}{clcl}
\hline $\mathrm{N}$ & Parameter pengamatan & $\begin{array}{c}\text { Heritabilitas } \\
\left(\mathrm{h}^{2}\right)\end{array}$ & Kriteria \\
\hline 1. & Berat biji per tanaman & 86.67 & Tinggi \\
2. & Berat 100 biji & 73.22 & Tinggi \\
3. & Jumlah biji per tanaman & 75.57 & Tinggi \\
4. & Jumlah polong per & 71.48 & Tinggi \\
& tanaman & & \\
5. & Umur panen & 81.41 & Tinggi \\
6. & Berat biji per petak & 65.80 & Tinggi \\
\hline
\end{tabular}

Tabel 6 menunjukkan bahwa, setiap parameter pengamatan mempunyai nilai heritabilitas yang tinggi. Nilai heritabilitas yang tinggi disebabkan 
oleh lingkungan yang relatif homogen, hal ini berarti penampilan suatu karakter lebih dipengaruhi oleh faktor genetik daripada faktor lingkungan. Hal ini berarti genotipe yang digunakan dalam penelitian ini memiliki peluang besar untuk mewariskan sifat-sifat tersebut pada keturunannya. Seleksi terhadap karakter yang memiliki heritabilitas tinggi akan lebih efektif dibanding dengan pengaruh lingkungan yang berperan dalam ekspresi karakter tersebut. Tingginya nilai heritabilitas merupakan modal utama untuk diadakannya seleksi tanaman, karena faktor genetik memberikan pengaruh yang lebih besar dibandingkan dengan faktor lingkungan.

Nasir (1999) menyatakan bahwa tingginya nilai heritabilitas dalam arti luas untuk karakter agronomi ini diduga disebabkan oleh relatif homogennya lokasi percobaan dan relatif kecilnya perbedaan antar plot percobaan baik dalam blok maupun antar blok itu sendiri. Program seleksi efektif jika nilai heritabilitas sedang sampai tinggi karena sifat tersebut kemungkinan besar diturunkan pada keturunannya (Poespodarsono, 1988; Dudly (1969) dalam Hidayat, 2003) Jadi dengan mengetahui besarnya nilai duga heritabilitas pada sifat tanaman, maka dapat dijadikan pedoman untuk arah seleksi selanjutnya. Dijelaskan oleh Knight (1977) dalam Hartatik (2007), bahwa heritabilitas Parameter pengamatan dengan nilai korelasi yang tinggi dan adalah bagian dari jumlah total fenotipe yang diakibatkan oleh pengaruh gen. Nilai heritabilitas bukanlah menunjukkan baikburuknya suatu sifat dan juga bukan merupakan suatu konstanta. Nilai ini lebih menunjukkan besarnya faktor genetik dan faktor lingkungan yang berperan dalam ekspresi suatu sifat.

\section{Korelasi Genotipe, Fenotipe dan Lingkungan}

Korelasi antar sifat tanaman biasanya diukur dengan koefisien korelasi. Dalam pemuliaan tanaman korelasi ini penting untuk mengukur derajat hubungan antara dua sifat atau lebih, baik dari segi genetik maupun non genetik. Tujuan dilakukannya penghitungan korelasi genetik adalah untuk menentukan hubungan antara dua sifat pada spesies tanaman.

Matrik korelasi pada Tabel 8 menunjukkan adanya hubungan positif pada semua parameter pengamatan kecuali pada sifat berat 100 biji dengan $\left(\mathrm{X}_{2}\right)$ dengan umur matang panen $\left(\mathrm{X}_{5}\right)$, dan antara sifat umur matang panen $\left(X_{5}\right)$ dengan berat biji per petak $\left(\mathrm{X}_{6}\right)$ mempunyai korelasi yang negatif. Hal ini berarti jika umur matang panen semakin cepat maka akan diikuti oleh penurunan berat 100 biji dan berat biji per petak.

positif menunjukkan adanya kontribusi yang cukup besar dalam 
meningkatkan produksi kedelai. peningkatan jumlah biji per tanaman. Korelasi antar sifat tanaman terdapat pada korelasi antara jumlah biji per tanaman $\left(\mathrm{X}_{3}\right)$ dengan jumlah polong per tanaman $\left(\mathrm{X}_{4}\right)$. Hal berarti bahwa

Astika (1991) dalam Poerwoko (1995) menyatakan bahwa pengetahuan tentang adanya korelasi antar sifat merupakan hal yang sangat penting dalam program pemuliaan tanaman, karena untuk memilih suatu bahan tanaman unggul, diperlukan seleksi dua atau
Nilai korelasi positif dan besar jumlah polong per tanaman mempunyai kontribusi yang besar terhadap ditampilkan dalam Tabel 7 sebagai berikut.

tiga sifat secara bersama-sama. Apabila diketahui adanya korelasi yang sangat erat antar sifat maka pemilihan sifat tertentu secara tidak langsung telah memilih sifat yang lain yang diperlukan dalam usaha memperoleh bahan tanaman unggul

Tabel 7. Korelasi Genotipe, Fenotipe dan Lingkungan

\begin{tabular}{cccccccc}
\hline $\mathrm{Xi}$ & & $\mathrm{X}_{1}$ & $\mathrm{X}_{2}$ & $\mathrm{X}_{3}$ & $\mathrm{X}_{4}$ & $\mathrm{X}_{5}$ & $\mathrm{X}_{6}$ \\
\hline $\mathrm{X}_{1}$ & $\mathrm{G}$ & 1.00 & 0.44 & 0.95 & 0.90 & 0.55 & 0.49 \\
& $\mathrm{~F}$ & & 0.43 & 0.88 & 0.77 & 0.42 & 0.36 \\
& $\mathrm{~L}$ & & 0.42 & 0.81 & 0.31 & -0.25 & -0.06 \\
$\mathrm{X}_{2}$ & $\mathrm{G}$ & & 1.00 & 0.16 & 0.08 & -0.16 & 0.40 \\
& $\mathrm{~F}$ & & & 0.12 & 0.02 & -0.09 & 0.36 \\
& $\mathrm{~L}$ & & & 0.02 & 0.15 & 0.14 & 0.28 \\
$\mathrm{X}_{3}$ & $\mathrm{G}$ & & & 1.00 & 1.03 & 0.65 & 0.29 \\
& $\mathrm{~F}$ & & & & 0.88 & 0.44 & 0.17 \\
& $\mathrm{~L}$ & & & & 0.45 & -0.32 & -0.14 \\
$\mathrm{X}_{4}$ & $\mathrm{G}$ & & & 1.00 & 0.69 & 0.11 \\
& $\mathrm{~F}$ & & & & & 0.52 & 0.10 \\
& $\mathrm{~L}$ & & & & & -0.03 & 0.09 \\
$\mathrm{X}_{5}$ & $\mathrm{G}$ & & & & & & -0.05 \\
& $\mathrm{~F}$ & & & & & & -0.05 \\
& $\mathrm{~L}$ & & & & & & \\
$\mathrm{X}_{6}$ & $\mathrm{G}$ & & & & & & \\
& $\mathrm{F}$ & & & & & & \\
& $\mathrm{L}$ & & & & & & \\
\hline Keterangan : $\mathrm{G}=$ Genotipe & & & &
\end{tabular}




\section{Korelasi dan Analisis Lintas}

Tabel 8. Pengaruh Langsung dan Tak Langsung Komponen Hasil terhadap Hasil

\begin{tabular}{lcccccll}
\hline $\mathrm{Xi}$ & $\mathrm{X}_{1}$ & $\mathrm{X}_{2}$ & $\mathrm{X}_{3}$ & $\mathrm{X}_{4}$ & $\mathrm{X}_{5}$ & Jumlah & $\mathrm{R}_{\mathrm{XY}}$ \\
\hline $\mathrm{X}_{1}$ & $\mathbf{4 . 5 7}$ & -0.53 & -2.50 & -0.86 & -0.49 & 0.49 & 0.49 \\
$\mathrm{X}_{2}$ & 2.03 & $\mathbf{- 1 . 1 9}$ & -0.41 & -0.08 & 0.05 & 0.40 & 0.40 \\
$\mathrm{X}_{3}$ & 4.33 & -0.19 & $\mathbf{- 2 . 6 4}$ & -0.98 & -0.23 & 0.29 & 0.29 \\
$\mathrm{X}_{4}$ & 4.13 & -0.10 & -2.73 & $\mathbf{- 0 . 9 5}$ & -0.24 & 0.11 & 0.11 \\
$\mathrm{X}_{5}$ & 2.50 & 0.19 & -1.72 & -0.66 & $\mathbf{- 0 . 3 5}$ & -0.05 & -0.05 \\
\hline
\end{tabular}

Keterangan : Tercetak tebal pada diagonal adalah pengaruh langsung

Pada Tabel 8 di atas nilai korelasi antara $\mathrm{X}$ dan $\mathrm{Y}$ pada $\mathrm{X}_{5}$ adalah $\quad-0.05$, sedangkan nilai pengaruh langsungnya -0.35 . Kedua nilai ini saling berdekatan sehingga seleksi secara langsung adalah berdasarkan pada umur matang panen $\left(\mathrm{X}_{5}\right)$. Pada Tabel 6 nilai koefisien korelasi $\mathrm{X}$ dan $\mathrm{Y}$ bernilai positif , pengaruh langsung $\mathrm{X}_{2}$ dan $\mathrm{X}_{3}$ masing bernilai negatif yaitu $\mathrm{X}_{2}$ $=-1.19$ dan $\mathrm{X}_{3}=-2.64$ maka dilakukan seleksi secara tak langsung terhadap $\mathrm{X}_{2}$ (berat 100 biji) dan $\mathrm{X}_{3}$ (jumlah biji per tanaman) masing masing melalui $\mathrm{X}_{1}$ (Berat biji per tanaman).

Pada hasil analisis lintas tidak terdapat nilai koefisien korelasi $\mathrm{X}$ dan $\mathrm{Y}$ yang negatif dengan pengaruh langsung yang positif sehingga tidak dilakukan seleksi secara terbatas. Jadi seleksi langsung, seleksi tak langsung dan seleksi terbatas berdasarkan hasil analisis lintas sifat agronominya dapat dilihat pada Tabel 9 berikut.

Tabel 9. Seleksi Langsung, Seleksi Tak Langsung dan Seleksi Terbatas Berdasarkan Hasil Analisis Lintas

\begin{tabular}{lc}
\hline \multicolumn{1}{c}{ Kriteria Seleksi } & Sifat Agronomi \\
\hline Seleksi Langsung & $\mathrm{X}_{5}$ \\
Seleksi Tak Langsung & $\mathrm{X}_{3}$ Lewat $\mathrm{X}_{1}$ \\
& $\mathrm{X}_{2}$ Lewat $\mathrm{X}_{1}$ \\
Seleksi Terbatas & - \\
\hline
\end{tabular}

Sedangkan model lintasan komponen hasil terhadap hasil disajikan pada Gambar 3 sebagai berikut. 


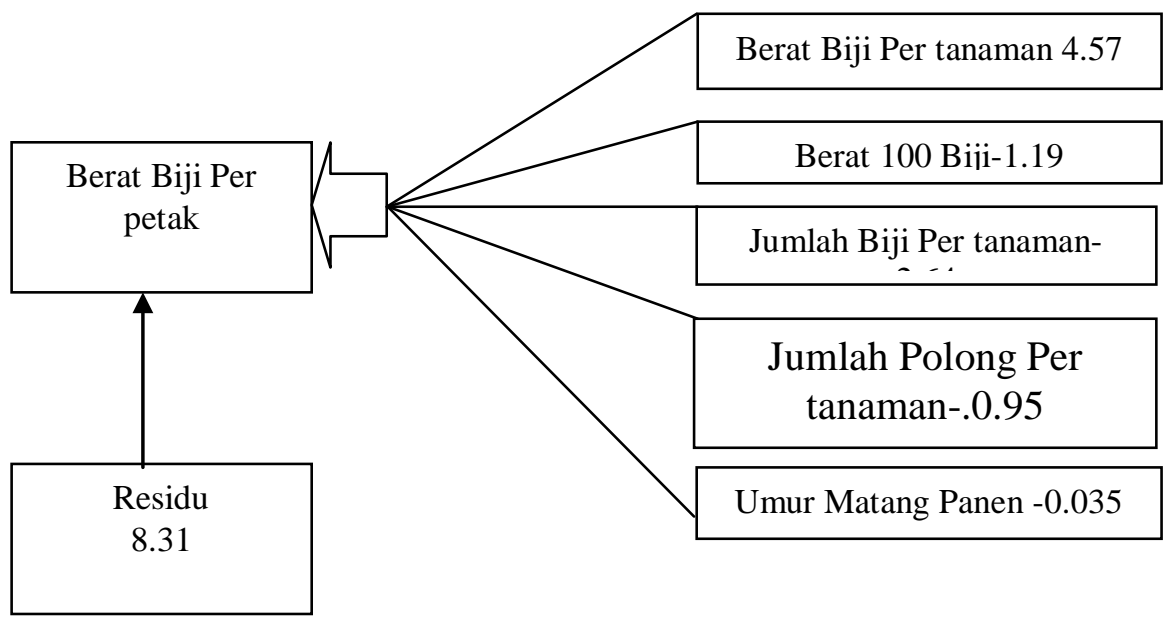

Gambar 3. Model Lintasan Komponen Hasil dan Pengaruh Langsung Terhadap Hasil Berat Biji Per petak.

Tabel 10. Rangkuman Nilai Korelasi $\left(\mathrm{R}_{\mathrm{XY}}\right)$,Pengaruh Langsung $\left(\mathrm{P}_{\mathrm{XY}}\right)$ dan Sumbangan Total Komponen Hasil Terhadap Hasil

\begin{tabular}{lcccc}
\hline \multicolumn{1}{c}{$\mathrm{Xi}$} & $\mathrm{R}_{\mathrm{XY}}$ & $\mathrm{P}_{\mathrm{XY}}$ & $\begin{array}{c}\text { Sumbangan } \\
\text { Total }\end{array}$ & Peringkat \\
\hline $\mathrm{X}_{1}$ & 0.49 & 4.57 & 225.13 & 1 \\
$\mathrm{X}_{2}$ & 0.40 & -1.19 & -47.73 & 4 \\
$\mathrm{X}_{3}$ & 0.29 & -2.64 & -77.31 & 5 \\
$\mathrm{X}_{4}$ & 0.11 & -0.95 & -10.00 & 3 \\
$\mathrm{X}_{5}$ & -0.05 & -0.35 & 1.59 & 2 \\
\hline Residu & & & 8.31 & \\
Total & & & 100.00 & \\
Peragam & & & & \\
\hline
\end{tabular}


Tabel 10 menunjukkan sumbangan langsung tertinggi komponen hasil terhadap berat biji per petak adalah berat biji per tanaman $\left(\mathrm{X}_{1}\right)$ dengan nilai 225.13 dan umur matang panen $\left(\mathrm{X}_{5}\right)$ dengan nilai 1.59. Residu untuk hasil analisis lintas antara komponen hasil terhadap hasil berat biji per per petak adalah 8.31 persen. Pengaruh sisa tidak mampu menjelaskan hubungan sebenarnya antara faktor peubah bebas dan respon. Dalam hal ini selain sifat agronomi yang diamati ada indikasi bahwa ada faktor luar yang menyumbangkan pengaruh.

Nilai sumbangan total merupakan perkalian korelasi masing-masing sifat terhadap biji dengan pengaruh langsung sifat agronomi tersebut Singh and Chaudhary (1979). Berat biji per tanaman merupakan fenotipe tanaman yang disebabkan oleh ekspresi genotipe dalam bentuk biji. Sehingga sifat tersebut memberikan sumbangan yang besar untuk meningkatkan hasil berat biji per petak.

\section{Analisis Multivariat}

Prinsip multivariat adalah perluasan dari univariat dan bivariat, dimana jika univariat atau bivariat hanya menghitung maksimal dua peubah. Dalam praktek multivariat semua peubah dianalis secara simultan atau bersamaan. Perbedaan tersebut merupakan keunggulan bagi multivariat. Hal ini disebabkan banyaknya percobaan atau fenomena yang secara alamiah melibatkan banyak peubah (Santoso, 2003).

Hasil analisis multivariat dari percobaan yang dilakukan ditunjukkan pada Tabel 9 sebagai berikut

Tabel 11. Analisis Multivariat Pada Genotipe yang Diteliti

\begin{tabular}{|c|c|c|c|c|c|}
\hline Sumber & DB & Jumlah & & & bel \\
\hline Keragaman & & Kuadrat & $\mathrm{U}(2,11,22)$ & 0.01 & 0.05 \\
\hline Genotipe & 11 & $8.45841 \mathrm{E}+15$ & $0.000134^{* *}$ & 0.016688 & 025354 \\
\hline Ulangan & 2 & $3.13869 \mathrm{E}+39$ & $0.306568^{\mathrm{ns}}$ & & \\
\hline Galat & 22 & $5.3141417 \mathrm{E}+13$ & & & \\
\hline Total & 35 & $5.75875 E+17$ & & & \\
\hline $\begin{array}{r}\text { Keterangan : ns } \\
* *\end{array}$ & & $\begin{array}{l}\text { ak berbeda nyata } \\
\text { beda sangat nyata }\end{array}$ & & & \\
\hline
\end{tabular}


Pada Tabel 11 disajikan hasil analisis multivariat dengan menggunakan Uji-U menunjukkan U hitung lebih kecil daripada U tabel, itu artinya terjadi perbedaan sangat nyata pada seleksi serempak komponen hasil kedelai. Perbedaan sangat nyata yang dihasilkan dari analisis multivariat menunjukkan populasi yang digunakan dalam penelitian ini memiliki keragaman genetik yang sangat besar, sehingga data yang diperoleh dapat digunakan untuk menghitung kemajuan respon daya hasil berdasarkan pada indeks seleksinya.
Setiap pemulia tanaman menginginkan kemajuan respon daya hasil semaksimum mungkin dengan melibatkan sifat agronomis seminimal mungkin. Berdasarkan pertimbangan ini, maka penggunaan enam sifat agronomik, yaitu berat biji per tanaman, berat 100 biji, jumlah biji per tanaman, jumlah polong per tanaman, umur panen, dan berat biji per petak dapat dipertimbangkan sebagai penyusun persamaan indeks terpilih. Kemajuan respon daya hasil (KG) dan kemajuan respon daya hasil parsial disajikan pada Tabel 12 sebagai berikut.

Tabel 12. Rangkuman Indeks Seleksi, Kemajuan Respon Daya Hasil dan Kemajuan Respon Daya Hasil Parsial

\begin{tabular}{|c|c|c|}
\hline Isi Indeks & KG & $K G_{p}$ \\
\hline $\begin{aligned} \mathrm{I}= & 4.212 \mathrm{Y}+3.820 \mathrm{X}_{1}+2.402 \mathrm{X}_{2} \\
& -1.999 \mathrm{X}_{3}-1.380 \mathrm{X}_{4}-4.263 \mathrm{X}_{5}\end{aligned}$ & 30.657 & 1.783 \\
\hline
\end{tabular}

Keterangan : KG = Kemajuan respon daya hasil

Berdasarkan Tabel 12, kemajuan respon daya hasil yang diperoleh dari persamaan indeks terpilih yaitu $30.657 \%$ untuk keenam sifat yang diseleksi secara simultan, dan $1.783 \%$ untuk kemajuan respon daya hasil parsialnya (berdasarkan sifat berat biji per-petak). Peorwoko (1995) menyatakan, bahwa dugaan kemajuan genetik secara simultan akan meningkat dengan bertambahnya sifat yang masuk kedalam indeks, namun tidak diikuti
KGp = Kemajuan respon daya hasil parsial

dengan kemajuan genetik secara parsial. Hal itu dapat dilihat pada Tabel 10, kemajuan genetik yang dihitung berdasarkan persamaan indeks terpilih yang melibatkan enam sifat agronomi sebesar $30.657 \%$, tetapi kemajuan genetik parsialnya hanya 1.783 persen.

Dixit et al. menyatakan, bahwa nilai harapan kemajuan genetik yang tinggi tidak selalu berhubungan dengan variasi genetik dan heritabilitas tinggi. 
Tetapi seleksi yang didasarkan pada penampilan fenotipik suatu sifat akan berhasil jika populasi yang diseleksi memiliki nilai harapan kemajuan respon daya hasil tinggi dan heritabilitas juga tinggi. Perbedaan dalam sifat yang terjadi pada individu di dalam populasi yang memiliki nilai heritabilitas tinggi bukan disebabkan oleh lingkungan, tetapi cenderung disebabkan oleh perbedaan genotipe tanaman.

Selanjutnya berdasarkan persamaan indeks terpilih, disusun peringkat genotipe yang diseleksi secara simultan melalui sifat-sifat komponen hasil yang diamati disajikan pada Tabel 13

Tabel 13. Peringkat Genotipe yang Diseleksi Secara Simultan Berdasarkan SifatSifat Agronomi yang Diamati

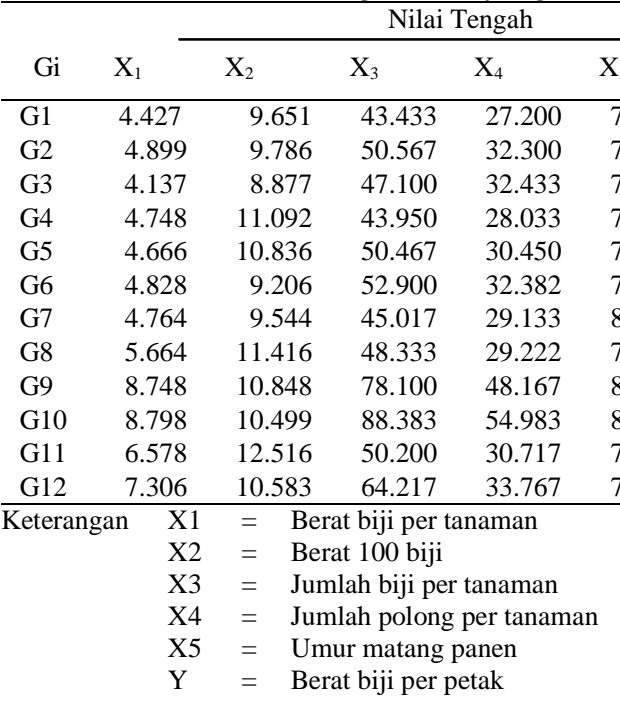

Berdasarkan Tabel 13 di atas, genotipe terbaik yang diseleksi secara simultan berdasarkan sifatsifat komponen hasil yang diamati (berat biji per tanaman, berat 100 biji, jumlah biji per tanaman, jumlah polong per tanaman, umur panen,

\begin{tabular}{|c|c|c|c|c|c|}
\hline$x_{5}$ & $\mathrm{Y}$ & \multicolumn{2}{|c|}{$\begin{array}{l}\text { Koefisien } \\
\text { Regresi, bi }\end{array}$} & $\begin{array}{l}\text { Kriteria } \\
\text { Seleksi }\end{array}$ & $\begin{array}{l}\text { Genoti } \\
\text { pe }\end{array}$ \\
\hline 76.000 & 631.464 & \multirow{9}{*}{\multicolumn{2}{|c|}{$\begin{array}{l}3.820 \\
2.402- \\
1.999- \\
1.380-4.263 \\
4.212\end{array}$}} & 2251.740 & 6 \\
\hline 74.667 & 525.314 & & & 1791.107 & 10 \\
\hline 77.000 & 680.478 & & & 2436.428 & 5 \\
\hline 76.000 & 524.564 & & & 1803.938 & 9 \\
\hline 75.667 & 459.960 & & & 1515.930 & 12 \\
\hline 74.000 & 586.337 & & & 2044.563 & 8 \\
\hline 80.333 & 589.358 & & & 2051.092 & 7 \\
\hline 78.000 & 835.190 & & & 3097.777 & 3 \\
\hline 80.667 & 544.245 & & & 1785.603 & 11 \\
\hline 81.000 & 791.312 & & & 2794.333 & 4 \\
\hline 73.000 & 819.548 & & & 3449.511 & 2 \\
\hline 76.333 & 1034.503 & & & 3910.730 & 1 \\
\hline G1 & $=\mathrm{Ba}$ & abi 1 & G7 & $=\mathrm{Ba}$ & abi 7 \\
\hline G2 & $\mathrm{Ba}$ & abi 2 & G8 & $\mathrm{Ba}$ & abi 8 \\
\hline G3 & $\mathrm{Ba}$ & abi 3 & G9 & $\mathrm{Ba}$ & abi 9 \\
\hline G4 & $\mathrm{Ba}$ & abi 4 & G10 & $\mathrm{Ba}$ & abi 10 \\
\hline G5 & $\mathrm{Ba}$ & abi 5 & G11 & Un & \\
\hline G6 & $\mathrm{Ba}$ & rabi 6 & G12 & Un & \\
\hline
\end{tabular}

berat biji per petak) adalah genotipe 12 (Unej 2). Selanjutnya berturutturut yang menempati peringkat kedua, ketiga dan keempat adalah genotipe Unej 1, Balitkabi 8, dan Balitkabi 10. 


\section{KESIMPULAN DAN SARAN}

Berdasarkan hasil peneitian dan analisis yang dilakukan dapat diambil kesimpulan sebagai berikut.

\section{Kesimpulan}

1. Berdasarkan nilai heritabilitas dan korelasi genetik antar sifatsifat komponen hasil, maka sifat berat biji per tanaman, berat 100 biji, jumlah biji per tanaman, jumlah polong per tanaman, umur panen, dan berat biji per petak, dapat dipergunakan sebagai sifat terpilih untuk seleksi terhadap daya hasil kedelai.

2. Respon daya hasil yang diduga berdasarkan analisis serempak yang melibatkan seluruh sifat komponen terpilih yaitu sebesar 30.657 persen.

3. Respon daya hasil yang diduga berdasarkan sifat berat biji per petak yaitu sebesar 1.783 persen.

\section{Saran}

Genotipe Unej 2 dapat dijadikan pertimbangan sebagai bahan percobaan selanjutnya bagi peneliti yang ingin melakukan percobaan dibidang pemuliaan tanaman.

\section{DAFTAR PUSTAKA}

AAK. 1998. Budidaya Tanaman Kedelai. Kanisius: Yogyakarta. Yogyakarta.

1995. Kedelai. Kanisius. 1989. Pemuliaan Tanaman. PT. Bina Aksara. Jakarta

Allard, R.W. 1989. Pemuliaan Tanaman. Bina Aksara. Jakarta.

1992. Pemuliaan

Tanaman. Rineka Cipta. Jakarta.

Alnopri. 2004. Variabilitas Genetik dan Heritabilitas Sifatsifat Pertumbuhan Bibit Tujuh Genotipe Kopi Robusta-Arabika. Ilmuilmu Pertanian Indonesia. 6 (2) 2004:91-96.

Anand, S.C and J.H. Torrie. 1963. Heritability of Yield and Other Traits and Interlationships Among Traits in F3 and F4 of Three Soybean Cross. Crop Sci. 3 : 508-511.

Brewbaker. 1983. Genetik Pertanian. Seri Lembaga Genetika Modern. Jakarta.

Chatterjee, S.D and B. Bhattacharyya. 1986. Selection Index in Indian 
Mustard. Indian J. Agr. Sci. 56 (3): 208-209.

Dixit, P.K. P.D. Bhagava, D.K. Saxena and L.K. Bhatia. 1969. Estimates of Genotypic Variability of Some Quantitative Characters in Groundnut (Arachis hypogea. L.). Indian J. Agr. Sci. 40: 197-202.

Firdaus, Azwar dan Muzirman. 2003. Budidaya Kedelai di Lahan Menggunakan Alat Tanam dan Alat Penyiang Semi Mekanis. Jurnal Stigma. 11: 150 158

Gasperz, V. 1995. Tekhnik Analisis dalam Percobaan Percobaan. Tarsito Bandung.

Gomez, A.K and A.A. Gomez. 1987. Statitically Procedures for Agricultural Reseatch. Second Edition. John Wiley and Sons. Inc. Canada.

Hallure, A.R. and J.B. Miranda FO. 1981. Quantitative Genetics in Maize Breeding. Low a State University Press. Arnes.
Hartatik, S. 2007. Pengantar Pemuliaan Tanaman. Jember: University Press. Jember.

2008. Pemuliaan Tanaman Aplikasi dan Prospek. Jember: University Press. Jember.

Hasnam, A.H. Nasution dan S. Somaatmadja. 1970. Correlation Between Yield Component Cross 1248 X TK 5. Comunication

Agriculture. 3: 23-30.

Hidayat, S. 2003. Keragaman dan Kokeragaman Genetik dan Sifat Hasil dan Komponen Hasil Tomat. Akta Agrosia. 6 (1): 7-11.

Johnson,A.R, dan D.W.Wichern.1982. Applied Multivariate Statistical Analysis. Printice. New Jersey: Hall. Inc. Englewood Cliff.

Kasno, A. 1992. Adaptasi dan Stabilitas Hasil GalurGalur Kacang Tanah Toleran Terhadap Kekeringan. Laporan Hasil Penelitian. Balai Penelitian Tanaman Pangan Malang. 
Kramer, Y.C. 1982. A First Course in Method of Multivariate Analysis. Virginia Polyteknik Institute and State University: Blacburg.

Kwon, S.H and J.h Torrie. 1964. Heritability of and Interrelationships Among Traits of Two Soybeans Populations. Crop Sci. 4 (2) 196-198.

Makmur, A. 1985. Pokok-pokok Pengantar Pemuliaan Tanaman. Jurusan Budidaya Pertanian Institut Pertanian Bogor. Bogor.

Mangoenddjoyo, W. 2003. Dasardasar Pemuliaan Tanaman. Kanisius: Yogyakarta.

Masnenah, E., Murdaningsih H.K., R. Setiamihardja, W. Astika, dan A. Baihaki. 1997. Parameter genetik karakter-karakter ketahanan terhadap penyakit karat kedelai dan beberapa karakter lainnya. Zuriat 8 (2), 57-63.

Miftahorrachman, Mangindan, H.F dan H Novarianto. 2000. Analisis lintas karakter vegetatif dan generatif kelapa. Zuriat, 2(1): 1117.
Mursito, D. 2003. Heritabilitas dan Sidik Lintas Karakter Fenotipik Beberapa Galur Kedelai. Agrosain, 6(2): 58-63.

Musa. 1978. Ciri Kestatistikan Beberapa sifat Agronomi Suatu Bahan Kegenetikan Kedelai. Sekolah Pascasarjana. IPB.Bogor.

Morrison, D.F. 1976. Multivariate Statistical Methods. Mc Grow-Hill Kogasuka Ttd : Tokyo.

Nasir, M. 1999, “Heritabilitas dan Kemajuan Genetik Harapan Karakter Agronomi Tanaman Lombok (Capsicum annuum L.)”. Dalam Habitat. (109) 11.p.1-8.

Pesek, J, and R.J. Baker. 1969.

Desiret Improvement in Relation to Selection Indices. Can. J. Plant Sci. 49: 803-804.

Pinaria, A., A. Baihaki, R. Setiamihardja dan A.A. Daradjat (1995) Variabilitas Genetik dan Heritabilitas KarakterKarakter Biomasa 53 genotipe Kedelai. Zuriat, 6 (2), 88-92. 
Poerwoko, M. S. 1995, Efektifitas dan Efisiensi Analisi Lintas Dalam Seleksi Simultan Zuriat Kedelai Melalui Persilangan Dialel Lengkap, Tidak Dipublikasikan. Desertasi. Bandung: Program Pascasarjana Universitas Padjadjaran.

Santoso, P.A. Suryadi, H. Subagiyo dan yuniasi. 2003. Kajian Adopsi Paket Teknologi Sistem Usaha Pertanian Kedelai Jawa Timur. Jurnal Pengkajian dan Pengembangan Tehnologi Pertanian,6:50-61

Setyowati, N, D, Suryati dan Maryanto. 2002. Pertumbuhan dan Hasil Beberapa Galur Harapan Kedelai pada Kerapatan Tanam Berbeda. Jurnal Akta Agrosia, 5(2): 47-52.

Soemartono, Nasrullah dan Hari Hartiko. 1992. Genetika Kuantitatif dan Bioteknologi Tanaman. Program PAU Bioteknologi UGM. Yogyakarta.

Solimun. 2001. Kaidah dan Metode Analisis Data. Fakultas MIPA Universitas Brawijaya. Malang.
Somaatmadja. S. 1985. Peningkatan Produksi Kedelai Melalui Perakitan Varietas. Badan Penelitian dan Pengembangan Pertanian. Pusat Penelitian dan Pengembangan Tanaman Pangan. Bogor.

Singh, R.K and B.D Chaudhary. 1979. Biometrical Methods Quantitative Genetics Analysis. Kalyani Publisher, Ludiana: New Delhi.

Srivasta and Carter. 1983. An Introduction to Applied Multivariate Statistic. Elservier Scince Publishing Co.Inc: New York.

Sudarmadji, R. Mardjono dan H. Sudarmo. 2007. Keragaman Genetik, Heritabilitas, dan Korelasi Genotipik Sifat-sifat Penting Tanaman Wijen. Litri. 13 (3): 88-92.

Yusuf, C. 1996. Kedelai dan Permasalahannya. Politeknik Pertanian Universitas Jember. 
